\title{
Evaluation of polymethylmethacrylate as ocular implant in rabbits subjected to evisceration
}

\author{
Arianne Pontes Oriál, Francisco de Assis Dórea Neto ${ }^{2}$, Luís Alberto dos Santos ${ }^{3}$, Evandro de Toledo Piza ${ }^{4}$, \\ Adriana Torrecilhas Jorge Brunelli ${ }^{5}$, Celina Tie Nishimori ${ }^{6}$, Ana Letícia Groszewicz de Souza ${ }^{7}$, \\ Deusdete Conceição Gomes Junior ${ }^{8}$ José Luiz Laus ${ }^{9}$
}

\begin{abstract}
Spheres of different types of material are used for the replacement of lost volume after removal of the eye bulb or its content to prevent contraction of the orbital cavity. The aim of this study was to evaluate the scope of polymethylmethacrylate (PMMA) used as intraocular implant in eviscerated rabbit eye. Twelve New Zealand rabbits underwent unilateral evisceration of the left eye, with subsequent implantation of PMMA sphere $12 \mathrm{~mm}$ in diameter. Clinical evaluation was performed daily during the first 15 days after surgery and every 15 days until the end of the study period (180 days). For the histopathological analysis, three animals per trial underwent enucleation at 15, 45, 90 and 180 days after evisceration. There was no wound dehiscence, signs of infection or implant extrusion in any animal throughout the study period. Histological examination revealed the formation of fibrovascular tissue around the implants. The PMMA behaved as inert and non-integrable.
\end{abstract}

Key words: intraocular prosthesis, enucleation, evisceration.

\section{ABSTRACT}

\section{Avaliação do polimetilmetacrilato como implante ocular em coelhos submetidos à evisceração}

Após a remoção do volume ocular ou de seu conteúdo, o implante de esferas de diferentes tipos de materiais previne a concentração da cavidade orbital. O objetivo deste estudo foi avaliar a esfera de polimetilmetacrilato (PMMA), utilizado como implante intraocular em coelhos submetidos à evisceração. Doze coelhos da raça Nova Zelândia foram submetidos à evisceração unilateral do olho esquerdo, com posterior implantação da esfera de PMMA com 12 mm de diâmetro. A avaliação clínica foi realizada diariamente nos primeiros 15 dias após a cirurgia e em intervalos de 15 dias até o final do período de estudo (180 dias). Para análise histopatológica, três animais por período experimental foram submetidos à enucleação aos 15, 45, 90 e 180 dias após a evisceração. Não foi observada deiscência da ferida, sinais de infecção ou extrusão do implante em nenhum dos animais durante todo o período do estudo. O exame histológico revelou a formação de tecido fibrovascular ao redor dos implantes. O PMMA comportou-se como material inerte e não- integrável.

Palavras-chave: prótese intraocular, enucleação, evisceração.

\footnotetext{
Received for publication on December 29 th 2011 and approved on August $7^{\text {th }}, 2012$.

${ }^{1}$ Veterinarian, Doctor. Departamento de Patologia e Clínicas, Universidade Federal da Bahia, Rua Adhemar de Barros, 500, Ondina, 40170-110, Salvador, Bahia, Brazil. arianneoria@ufba.br (corresponding author).

2 Veterinarian, Doctor. União Metropolitana de Educação e Cultura (UNIME), Avenida Luis Tarquinio Pontes, 600, Centro, Lauro de Freitas, 41720-040, Salvador, Bahia, Brazil. d.oria@terra.com.br

${ }^{3}$ Engineer, PhD. Escola de Engenharia, Departamento de Materiais, Universidade Federal do Rio Grande do Sul, Avenida Paulo Gama, 110, $7^{\circ}$ andar, Farroupilha, 90046-900, Porto Alegre, Rio Grande do Sul, Brazil. luis.santos@ufrgs.br

${ }^{4}$ Veterinarian, Doctor. Private Practice, IPEV, Rio de Janeiro, Rio de Janeiro, Brazil. ipevlab@ig.com.br

${ }^{5}$ Veterinarian, Doctor. Private Practice, IPEV, Franca, São Paulo, Brazil. dribrunelli@hotmail.com

Veterinarian, Doctor. Universidade Federal de Goiás, Campus Samambaia II, Prédio da Reitoria, 74001-970, Goiânia, Goiás, Brazil. celinatie@yahoo.com.br

${ }^{7}$ Veterinarian, Doctor. Private Practice, IPEV, Curitiba, Brazil. analetsmv@yahoo.com.br

${ }^{8}$ Veterinarian. Master student of Universidade Estadual Paulista "Júlio de Mesquita Filho", Via de Acesso Professor Paulo Donato Castellane, s/n, 14884-900, Jaboticabal, São Paulo, Brazil.veterinarioufba@yahoo.com.br

${ }^{9}$ Veterinarian, PhD. Faculdade de Ciências Agrárias e Veterinárias, Universidade Estadual Paulista "Júlio de Mesquita Filho", Via de Acesso Professsor Paulo Donato Castellane s/n, 14884-900, Jaboticabal, São Paulo, Brazil. jllaus@fcav.unesp.br
}

Rev. Ceres, Viçosa, v. 59, n.4, p. 452-457, jul/ago, 2012 


\section{INTRODUCTION}

Spheres of different types of material are used for the replacement of lost volume after removal of the eye bulb or its content to prevent contraction of the orbital cavity. After World War II, polymethylmethacrylate (PMMA) spheres replaced glass spheres, both called nonintegratable spheres (Moshfeghi et al., 2000). A remarkable change in the types of material used for the fabrication of spheres occurred in the 1980s, with the appearance of integratable implants such as hydroxyapatite (Moshfeghi et al., 2000; Tari et al., 2009) and polyethylene (Moshfeghi et al., 2000; Schellini et al., 2003).

However the PMMA microspheres are still routinely used in veterinary medicine for improvement of the cosmetic disfigurement of patients (Spiess \& Wallin Häkanson, 1999), and also because of its low cost, convenience, and almost nonexistent adverse effects (Rahal et al., 2000b; Talieri et al., 2004), therefore, the aim of this study was to evaluate PMMA spheres as intraocular implants in rabbits subjected to evisceration.

\section{METHODS}

\section{Fabrication and gross examination of the polymethylmethacrylate (PMMA) implants}

Spheres of PMMA (Acrílico auto-polimerizante JET: Laboratório Clássico) are made by mixing a powder (polymer) to liquid (monomer) ratio of 1:1 in a sterile bowl to obtain a liquid slurry, according to the manufacturer's instructions. Then the paste was injected using a 3-ml syringe into a prefabricated silicone mold for manufacturing 12-mm balls. After 20 minutes (time required for hardening and cooling), the ball was removed from the mold. Immediately after, the balls were individually packed and sterilized by autoclaving, at $132^{\circ} \mathrm{C}$ for 20 minutes following the procedures of Nasisse et al. (1988).

\section{Animal study}

Twelve adult New Zealand rabbits (Oryctolagus cuniculus) were used, males and females weighing 2.4 to $3.3 \mathrm{~kg}$, obtained from the Sector of Rabbit Breeding, Universidade Estadual Paulista (UNESP), Jaboticabal Campus.

\section{Surgical procedure}

All surgical procedures were performed by the same surgeon with the animal under general inhalation anesthesia with halothane (Halothane - Cristália). The left eye of each animal was standardized to be used for evisceration. A lateral canthotomy was performed to facilitate the surgical maneuvers. An incision was made in the bulbar conjunctiva with a conjunctival forceps 2 to 4 $\mathrm{mm}$ distant from the limbus, creating a flap measuring approximately $17 \mathrm{~mm}$ in length. An incision was then made in the scleral bed with a No. 15 surgical knife and enlarged about $15 \mathrm{~mm}$. The crystalline content was removed with an evisceration spoon and a small Freer separator was used in circular movements to separate the intraocular structures from the scleral cap. Next, a delicate toothed forceps was used to remove intact uveal tissue. Intraocular remnants were removed with swabs. During the procedures, the ocular surface was systematically irrigated with $0.9 \%$ physiological saline using a syringe coupled to an irrigation cannula. The implants were inserted into the corneoscleral cap with an implant introducer with a circumference of 10 to $16 \mathrm{~mm}$. The scleral and conjunctival incisions were closed with simple continuous 6-0 polyglactin 910 sutures (Vicryl - Ethicon) and the lateral canthotomy was repaired with simple interrupted 5-0 polyglactin 910 sutures (Vicryl - Ethicon).

\section{Postoperative care}

Immediately after surgery, the rabbits received ketoprofen (Ketofen - Meryal) at a dosage of $1 \mathrm{mg} / \mathrm{kg}$ body weight, subcutaneously, and then at regular 12-hour intervals for the first 3 postoperative days. To provide postoperative comfort to the animals, $0.05 \mathrm{mg} / \mathrm{kg}$ buprenorphine hydrochloride (Tengesic - ScheringPlough) was administered subcutaneously at regular 12hour intervals for the first 5 postoperative days. The ocular surface was cleaned daily with $0.9 \%$ saline and ciprofloxacin ointment (Ciloxan -Alcon) was administered topically at 12 -hour intervals for 15 consecutive days. No protective collar was needed at any time during the experiment.

\section{Clinical evaluation of the Animals}

Clinical evaluations were performed daily for the first 15 postoperative days and then at 15-day intervals until the end of the experimental period. For this purpose we used the slit biomicroscopy (Portable slit lamp SL - Kowa), and fluorescein eye stain (fluorescein strips - Ophthalmos). Blepharospasm, blefaroedema, ocular discharge, chemosis, corneal edema and neovascularization and the presence of blood or clot in the corneal implant interface were also evaluated. All ocular manifestations considered to be abnormal during postoperative evolution were recorded. Postoperative complications and other ocular manifestations were investigated.

\section{Histological analysis}

Three animals were enucleated after euthanasia with an overdose of barbiturates (Thiopentax - Cristália) at 15, 45, 90 and 180 days after surgery and the eyes were immersed in $10 \%$ buffered formalin. The corneoscleral cap was separated from the implant and embedded in paraffin 
using routine techniques. Paramedial sagittal 3-4 $\mu$ m thick sections were obtained and stained with hematoxylineosin.

\section{RESULTS}

\section{Gross examination of the PMMA implant}

The PMMA spheres weighed $1.2 \mathrm{~g}$. The gross inspection showed that the external surface of the implant had a solid, smooth and compact aspect with no evidence of a pore or channel structure (Figure 1A). On the internal surface there was no system of pores, but only a compact and irregular surface (Figure 1B). The pinching test was negative, since it was not possible to deform the implant (Figure 1C) that was unable to be penetrated with a $25 \times 7$ needle (Figure 1D).

\section{Clinical evaluation of the animals}

No systemic events were observed in any of the animals. There was no scleral or conjunctival wound dehiscence and no signs of infection or implant extrusion were observed in any animal.
The blepharospasm and blepharedema remained present in all animals, moderately to intense in the first postoperative day and slightly through the third day, decreasing gradually to become absent starting from the fifth day. Intense chemosis were more acutely manifested in the conjunctiva of the nictitating membrane in the first day after implantation (Figure 2A), becoming moderate in the second day, discrete in the third day and disappearing after five days. The corneal neovascularization was found to be discreet from the fourth day, originating from the limbus to the central cornea, with progression in centripetal direction until near the center of the cornea, in the form of very engorged vessels (Figure 2B) even approximately at day 15 . In the subsequent periods, the vessels have become increasingly dispersed, less engorged and distributed throughout the corneal surface, moderately until day 45 , and slightly through the last assessment period (180 days) (Figure 2C). The corneal edema appeared in all periods, discrete and its intensity did not compromise the viewing of content on the cornea-implant interface

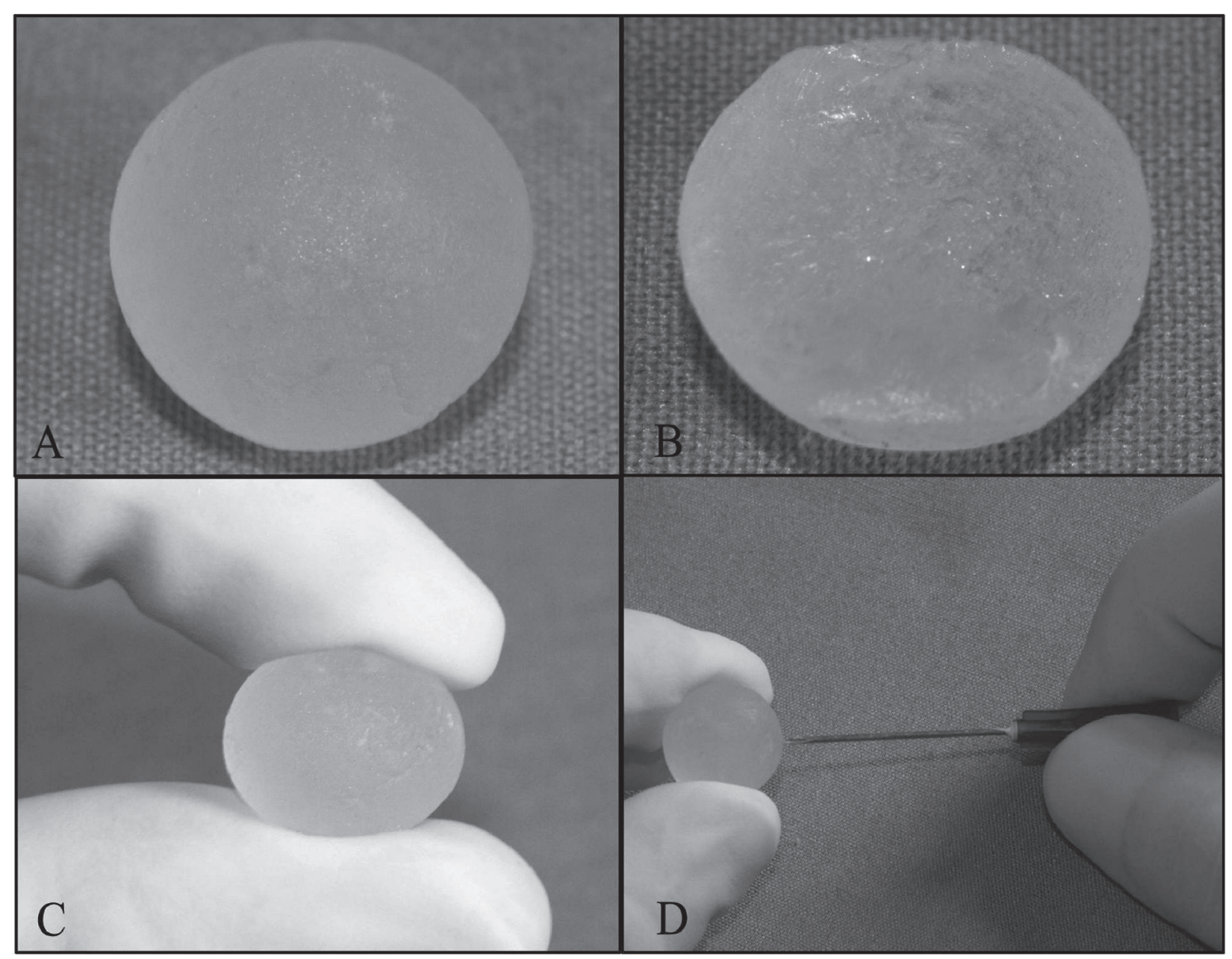

Figure 1. The external (A) and internal (B) surface of the polymethylmethacrylate sphere. Note the smooth and compact aspect of the implant (C). The pinching test (D). Attempt to penetrate the implant with a $25 \times 7$ needle. 
or the implant itself. Hemorrhagic content was observed in the cornea-implant interface immediately after surgery for moderate to severe from the first to seventh day (Figure $2 \mathrm{~A})$. In the subsequent period, it became moderate and the color started to lose its intensity. From day 15, it showed a low profile, with some bruises and individually organized. Over the time the entire contents of the corneaimplant interface gradually disappeared before it became absent on the day 45 . There were only tiny points of blackened color in places where previously a hematoma had been visualized (Figure 2C).

A white non-purulent ocular discharge was noted in all animals throughout the study period.

\section{Histological analysis}

The measurement of enucleated eyes, ranged from 14 to $16 \mathrm{~mm}$ in the sagittal direction, between the cornea and sclera. In the coronal direction, sclera to sclera, they measured $13 \mathrm{~mm}$ in all eyes. At 15 days, the corneas had increased their convexity, which was not observed in the subsequent periods, at 45, 90 and 180 days.

Prior to histological processing, the implants were easily detached from the corneal-scleral layer, with no macroscopic evidence of residual material on the ball. All of them were closely surrounded by a fibrocellular tissue capsule of variable thickness in all periods.

A well collagenized granulation tissue at an advanced stage of maturity was observed at 15 days. During the periods that followed, i.e., 45, 90 and 180 days, we found fibrocellular tissue detachment. Also at 15 days, areas were identified in the cornea-scleral implant and scleraimplanta blood collection contained by mature granulation tissue, more evident in the cornea-implant space. The corneal stroma was invaded by granulation tissue and mixed inflammatory infiltrate from the limbus, with the presence of numerous capillaries. There was disorganization of the stromal lamellae in a diffuse way. Cover consisting of fibroblasts and collagen fibers, derived from the sclera, was observed closely surrounding the implant, with absence of acute inflammatory reactivity or conspicuous presence of macrophages.

At 45 days, capillarizationin the cornea was observed with mild eosinophilic infiltrate between the capillaries in the stroma. Under the Descemet membrane, a band with multiple siderophores was observed. In areas of the sclera, fibrous bundles of dense collagen were identified interspersed with elongated mature fibroblasts. In the fibrocellular tissue, a fibroblastic proliferation was observed interspersed with collagen fibers (Figure 3A).

Very thin strips of dystrophic calcification in the corneal epithelium with a fibrocellular organized band of tissue surrounding the implant was present at 90 days. A portion of this band of tissue adjacent to the sclera showed fibrocellular disorganization with greater capillarity and remnant of granulation tissue from previous periods.

At 180 days, most of the capillaries in the cornea were no longer identified and had dense fibrous stroma, allowing the occurrence of artifacts in the histological technique (smaller room at the time of the razor cut). It was observed the disappearance of the fibrocellular cap in some places, whereas in others, thre was a marked decrease in thickness and scleral narrowing, with focal remnants of fibrous granulation tissue (Figure 3B).

\section{DISCUSSION}

According to Lloyd et al., (2001), the removal of the eye or its internal content requires the insertion of a solid implant to maintain the orbital volume and cosmetics. In the present study, we evaluated the behavior of PMMA implant in rabbits subjected to evisceration.

Scanning electron microscopy of the implant was not performed as Mishima et al., 1991, working with a PMMA orbital implant used in human patients, observed an irregular and rough surface.

In the present study, the clinical evaluation of the animals indicated that the material was well tolerated, in contrast to other investigators. In medicine, PMMA implant complications are of late occurrence (Schellini et

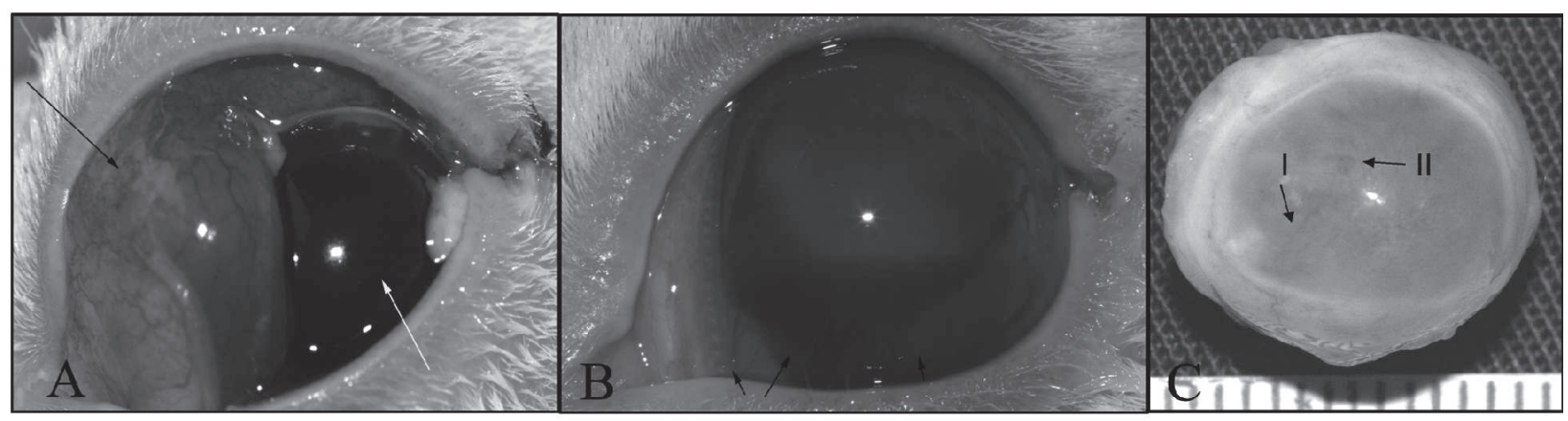

Figure 2. (A) Intense chemosis (black arrow) and hemorrhagic content in the cornea- implant interface immediately after surgery (white arrow). (B) Corneal neovascularization (black arrows). (C) Note the presence of corneal transparency and discrete neovascularization (I) and black dots in the cornea- implant interface (II). 


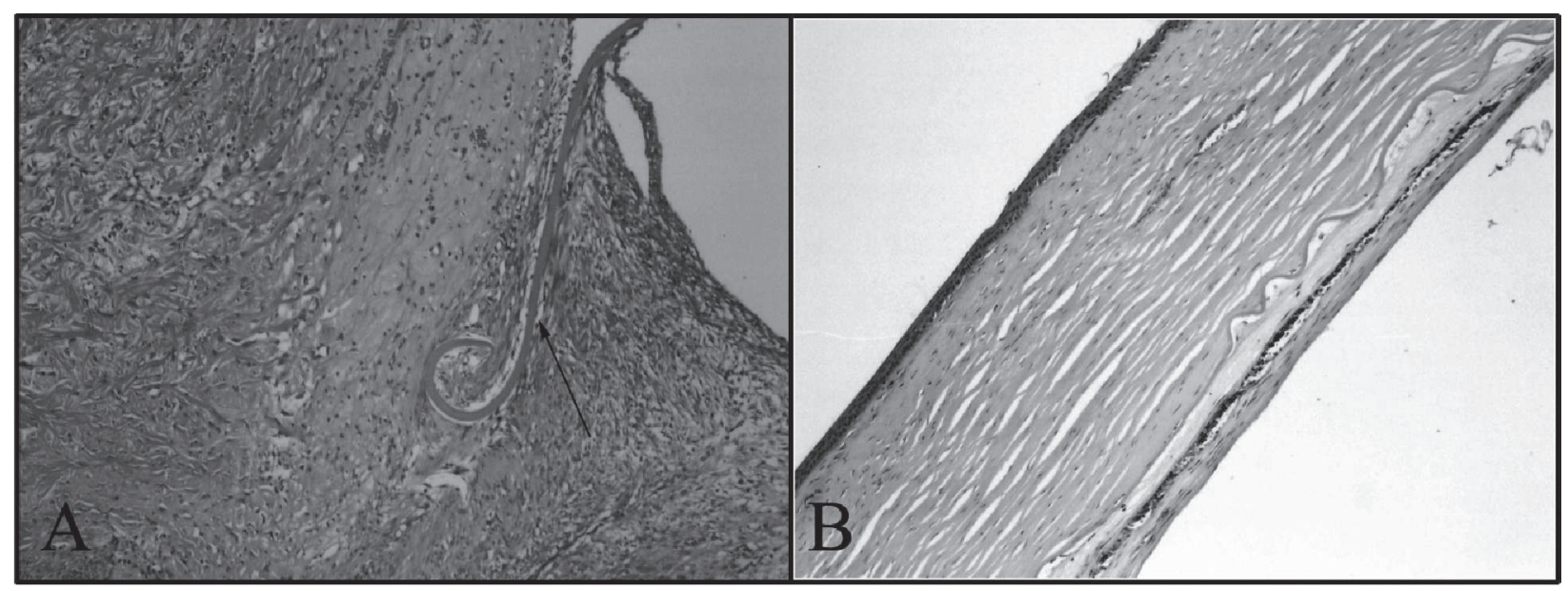

Figure 3. Photomicrographs sections of the cornea of rabbit eyes after implantation of polymethylmethacrylate spheres. In (A) 15 days after implantation note in the limbo - corneal region, the Descemet's membrane included in chronic inflammatory reaction in the limbus (arrow) with mixed infiltrate and fibrosis (10x). In (B) at 180 days, note the densification of fibrous stroma and a fibrocellular layer under the cornea and the presence of hemosiderin calcified deposits in the cornea fibrocellular interface (10x). Hematoxylin eosin stain (HE).

al., 2000), however Schellini et al. (2007) described that the extrusion of the sphere can occur, due to suture dehiscence, in the range of a week to two years postsurgery. In veterinary medicine, ocular secretion and decrease of orbital volume can be noted in animals after more than one year of the surgical procedure (Rahal et al., 2000a). Corneal ulcer, between 2 to 11 days postsurgery and keratoconjunctivitis, between 2 to 16 weeks of the post-operative period were also described by Lin et al. (2007).

Postoperative edema was documented by Koch (1981) with the use of silicon spheres in dogs. According to the author, the resolution took place between the fifth and seventh days, similar to our findings, and the same author observed intense corneal vascularizationin the early stages of post-operative period, tending to lessen in subsequent periods. Rahal et al., (2000a), using PMMA implants in rats, noticed the same changes and resolution.

The structural changes of the cornea verified by macro and microscopic examination did not lead to alterations in its transparency that prevented visualization of the cornea-implant interface and the implant itself. Nasisse et al. (1988) by implanting silicone and Rahal et al. (2000b), PMMA, reported that the corneal changes may result from malnutrition of the endothelium, with progressive degeneration of the lamellae. However, Brightman et al. (1977) and Koch (1981), evaluating dogs that received silicone implants, discussed that the appearance of the cornea after surgery depends on the surgical conditions, since the endothelial disorder at the time of surgery would interfere with the final result.

Schellini et al. (2003) and Thakker et al. (2004) state that tissue integration into the sphere depends on various factors such as pore size, the type of material used as a cover and the host tissue reaction. Schellini et al. (2003) also points out that porous materials such as porous polyethylene and, to a lesser extent, synthetic hydroxyapatite, allow fibrovascular growth, thus facilitating the integration of the implant with the host tissue.

The spheres used in this study were made of a nonintegrable material and had no macropores that prevented fibrovascular growth into its interior. These results corroborate with the findings of Mariolani et al. (1993), who reported that when the polymeric material is introduced into the body, it causes inflammation, with little significant reaction, and the implant is encapsulated by fibrous tissue.

The contraction of the corneal-scleral layer around the implant resulted in similar size to the sphere implanted, which was also described by Brightman et al. (1977) and Rahal et al. (2000a).

According to Jordan et al. (2002), an ideal implant should have characteristics such as being biocompatible, bioinert, non-toxic and non-allergenic and allowing easy peg placement for fixation of the prosthesis, in addition to promoting adequate motility of the prosthesis, with low cost and stability over time. The polymethylmethacrylate (PMMA) does not have these features, however during the trial period, it proved to be biocompatible, inert, nontoxic, non-allergenic, stable and of low cost.

\section{CONCLUSIONS}

The polymethylmethacrylate (PMMA) behaved as an inert and nonintegrated material. The lack of incorporation of the PMMA by the fibrovascular tissue might be related to the absence of porosity. 


\section{ACKNOWLEDGMENTS}

The authors would like to thank CNPq (Conselho Nacional de Desenvolvimento Científico e Tecnológico) for the scholarship provided.

The research protocols were approved by the Ethics and Animal Well-Being Committee of the Faculdade de Ciências Agrárias e Veterinárias, UNESP, Jaboticabal Campus. In addition, the bioethical guidelines of the Association for Research in Vision and Ophthalmology (National Institutes of Health, Publication No. 85-23: Revised, 1985) for the use of animals in vision research were followed.

\section{REFERENCES}

Brightman AH, Magrane WG, Huff RW \& Helper LC (1977) Intraocular Prosthesis in the dog. Journal of the American Animal Hospital Association, 4:481-485.

Jordan DR, Brownstein S, Gilberg S, Matthew B, Mawn L \& Khouri L (2002) Investigation of a bioresorbable orbital implant. Ophthalmic Plastic \& Reconstructive Surgery, 18:342-8.

Koch SA (1981) Intraocular prothesis in the dog and cat: the failures. Journal of the American Veterinary Medical Association, $9: 883-885$

Lin CT, Hu CK, Liu CH \& Yeh LS (2007) Surgical outcome and ocular complications of evisceration and intraocular prosthesis implantation in dogs with end stage glaucoma: a review of 20 cases. The Journal of veterinary medical science / The Japanese Society of Veterinary Science, 8:847-850.

Lloyd AW, Faragher RGA \& Denyer SP (2001) Ocular biomaterials and implants. Biomaterials, 22:769-85.

Mariolani JRL, Belangero WD \& Arruda ACF (1993) Resposta provocada pelas interações biológicas e mecânicas entre material de implante e tecido receptor. Acta Ortopédica Brasileira, $2: 1-6$.

Mishima K, Matsunaga N \& Amemiya T (1991) Methylmethacrylate implants: a scanning eletron microscopic study. Annals of Plastic Surgery, 6:561-563.

Moshfeghi DM, Moshfeghi AA \& Finger PT (2000) Enucleation. Survey of Ophthalmology, 44:277-301.

Nasisse MP, VanEe RT, Munger RJ \& Davidson MG (1988) Use of methyl methacrylate orbital prostheses in dogs and cats: 78 cases (1980-1986). Journal of the American Veterinary Medical Association, 4:539-542.

Rahal SC, Bergamo FMM \& Ishiy HM (2000a) Prótese intraocular de resina acrílica em cães e gatos. Arquivo Brasileiro de Medicina Veterinária e Zootecnia, 4:319-324.

Rahal SC, Schellini SA, Marques MEA \& Ranzani JJT (2000b) Emprego de prótese intra-ocular de resina acrílica. Estudo experimental em ratos. Brazilian Journal of Veterinary Research and Animal Science, 4:286-290.

Schellini SA, Hoyama E, Padovani CR, Ferreira VLR \& Roça R (2000) Complicações com o uso de esferas não integráveis e integráveis na reconstrução da cavidade anoftálmica. Arquivos Brasileiros de Oftalmologia, 3:175-178.

Schellini SA, Marques ME, Padovani CR, Taga EM \& Rossa R (2003) Comparison of synthetic hydroxyapatite and porous polyethylene implants in eviscerated rabbit eyes. Ophthalmic Plastic \& Reconstructive Surgery, 19:136-139.
Schellini SA, Ishida FK \& Padovani CR (2007) Extrusão dos implantes em portadores de cavidade anoftálmica. Arquivo Brasileiro de Oftalmologia, 70:752-755.

Spiess BM \& Wallin-Häkanson N (1999) Diseases of the canine orbit. In: Gelatt KN (Ed.) Veterinary ophthalmology. 3ed. Philadelphia, Lippincott Williams \& Wilkins. p.511-533.

Talieri IC, Buquera LEC, Oriá AP, Brunelli ATJ, Almeida D \& Laus JL (2004) Use of methyl methacrylate, moulded in its paste phase, to fill the orbital cavity of dogs, after exenteration in cases of ophthalmic neoplasias: a report of three cases. Ciência Rural, 2:567-571.

Tari AS, Malihi M, Kasaee A, Tabatabaie SZ, Hamzedust K, Musavi MF \& Rajabi MT (2009) Enucleation With Hydroxyapatite Implantation Versus Evisceration Plus Scleral Quadrisection and Alloplastic Implantation. Ophthalmic Plastic \& Reconstructive Surgery, 25:130-133.

Thakker MM, Fay AM, Pieroth L \& Rubin PA (2004) Fibrovascular ingrowth into hydroxyapatite and porous polyethylene orbital implants wrapped with acellular dermis. Ophthalmic Plastic \& Reconstructive Surgery, 20:368-3. 